\title{
A Developed Spectrophotometric Method for Thorium Determination using Alizarin Red S Dye in Different Types of its Bearing Rocks
}

\author{
Hisham K. Fouad ${ }^{1}$, Saeyda A. Abu Elenein ${ }^{2}$, Randa M. Elrakaiby ${ }^{3}$, Shaimaa S. Abdulmoteleb ${ }^{4}$ \\ ${ }^{1}$ Analytical Chemistry Department, P.O box 530, Maadi, Cairo, Egypt \\ ${ }^{2}$ Menofia University, Faculty of Science, Chemistry Department \\ Nuclear Materials Authority, Analytical Chemistry Department
}

\begin{abstract}
The spectrophotometric determination of thorium from its different bearing rock types such as Thorite, Trachyte, and Ring complexes using the well known chromogenic alizarin red $S$ (ARS) dye was proposed in the present work. Optimization of the formed thorium-alizarin red $S$ complex was performed by studying several parameters such as different acid media, suitable buffer pH, dye concentration, duration time of the formed complex, and thorium concentration (calibration curve). The optimized method was applied to different rock types bearing thorium as well as standard phosphate (2). Interference due to major oxides was treated by partial decomposition of rock samples, which minimized their concentrations together with complete leaching of thorium facilitated the accurate determination of thorium in those samples. On the other hand, interference due to high uranium concentrations was overcome by its selective extraction using trioctylamine in xylene. Beer's law was obeyed from a concentration of $1 \mu \mathrm{g} \mathrm{mI^{1 }}$ till $80 \mu \mathrm{g} \mathrm{I}^{1}$ with a molar absorptivity value of $0.42 \times 10^{3} \mathrm{l} \mathrm{mol}^{-1} \mathrm{~cm}^{-1}$. The percentage relative standard deviation (\%RSD) for 10 replicate measurements of $10 \mu \mathrm{g} \mathrm{I}^{-1}$ thorium was $2.23 \%$.
\end{abstract}

Keywords: Spectrophotometric, determination, thorium, alizarin, rocks

\section{Introduction}

Spectrophotometry is always an acceptable alternative method for total element determination (e.g. either totaluranium or total-thorium determination), due to its robustness and acceptable precision and accuracy, associated with its lower cost compared with other techniques. The critical point against the use of spectrophotometry for determination of uranium and thorium is generally associated with low sensitivity and selectivity of the spectrophotometric determinations. These limitations can be solved by using selective extraction materials. [1] In the proposed methods spectrophotometric detection was chosen to the development of simple and inexpensive systems easily adaptable to field measurements.

Many types of reagents were applied for spectrophotometric analysis of thorium, these include; arsenazo III [2], 2-(4sulphophenylazo)chromotropic acid (SPADNS) [3], ßhydronaphth hazarin [4], Quercetin [5], Morin [6], $\alpha$ benzoin oxime [7] and thoron [8] that showed great performance for thorium analysis in most samples.

A selective anion-exchange separation and spectrophotometric method was developed for the determination of uranium and thorium in phosphate rocks. Uranium and thorium were adsorbed by anion-exchange on an Amberlite $\mathrm{CG} 400\left(\mathrm{NO}_{3}{ }^{-}\right)$column from the sample solution then eluted consecutively with $6.6 \mathrm{M}$ nitric acid and $0.1 M$ nitric acid, respectively. Uranium and thorium in the respective effluents are determined spectrophotometrically with Arsenazo III. [9]
Among the anthraquinone dyes, alizarin and its derivatives (1,2 dihydroxy-3-anthraquinone sulphonic acid) has found application in the micro determination of a number of metals [10]. The presence of quinoid oxygen, with two hydroxyl groups at $\alpha$ - and $\beta$ - positions makes it very suitable for chelation. Coordination bonding of metal to dye molecule occurs when phenolic group of dye is partly oxidized and partly ionized and metal gets bound. Oxidized quinonic oxygen begins to form a coordination with the same metal and thus chelate is formed which facilitates the charge transfer (CT) from ligand to metal ion, which is responsible for its chromophoric properties. This property has been exploited in the detection and determination of a number of transition metals [11]. The presence of sulphonate group in the molecule adds further reactivity to the molecule.

The electrochemical behavior of ARS has been also studied in connection with voltametric determination of metals like $\mathrm{Ca}$, Sc and Al [12-14]. The staining of gel with ARS has been reported in which stained gel was washed and washing was monitored using spectrophotometry [15].

The spectrophotometric determination of metal ions using ARS and other anthraquinone derivatives continued to hold interest to scientists $[\mathbf{1 6}, \mathbf{1 7}]$. It is well known that the ease of formation of a complex with dye, thus stability of the complex decides its applicatory importance. The dyes of hydroxyl phenyl group in alizarin red $\mathrm{S}$ gave colored chelates with metal ions in solution and the pronounced chelating properties of these dyes must be due to the presence of donar groups like $-\mathrm{COOH},-\mathrm{OH}$ and $-\mathrm{O}$.

The analytical chemistry department of the Nuclear Materials Authority was concerned with the determination of thorium in high and low concentrations as in monazite 


\section{International Journal of Science and Research (IJSR) \\ ISSN (Online): 2319-7064 \\ Index Copernicus Value (2013): 6.14 | Impact Factor (2014): 5.611}

sand and different rock types bearing thorium concerning geochemical studies. Therefore, an effort was made to develop a selective, reproducible and sensitive method for thorium (IV) determination using the well known alizarin red $\mathrm{S}$ dye in different types of rocks bearing thorium.

\section{Experimental}

\section{Chemicals and reagents}

Analytical grade and chemical pure reagents were used in all experiments, such as thorium nitrate (Stream chemicals, USA), alizarin red S (BDH, England), perchloric acid, nitric acid, hydrochloric acid (Panreac, Spain), hydrofluoric acid, sulphuric acid (Riedel De Haën, Germany), glacial acetic acid (Fisher, Switzerland), sodium acetate, hydrogen peroxide and trioctyl amine (Merck, Germany).

\section{Apparatus}

A double beam UV - Visible spectrophotometer model Labomade (UVD 2950), USA, was used for measuring the absorbance of thorium - dye complex. All measurements were carried out at room temperature (about $25^{\circ} \mathrm{C}, \pm 5^{\circ} \mathrm{C}$ ). A Jenway $\mathrm{pH}$ meter was used for recording the $\mathrm{pH}$ of different solutions. It was calibrated regularly with two successive buffer solutions (4 and 7 or 7 and 10).

\section{Decomposition Procedure}

A decomposition procedure was proposed by authors, [18] which facilitated partial decomposition of major oxides together with total leaching of thorium, an advantage for minimizing the concentration of accompanying elements hence lowering their interference effect during thorium determination. All rock samples applied for thorium determination were partially decomposed using the following procedure to facilitate total leaching of thorium for accurate determination. The decomposition method was given as follows:

1) In a teflon beaker, $20 \mathrm{ml} \mathrm{HF}$ were added to a weight of $0.2 \mathrm{~g}$ from each ground sample.

2) Heat till dryness then add $15 \mathrm{ml}$ of dilute $\mathrm{HF}$ (1:1) and filter.

3) The precipitate was treated with $10 \mathrm{ml}$ concentrated $\mathrm{HClO}_{4}$ and $5 \mathrm{ml}$ concentrated $\mathrm{HNO}_{3}(15.55 \mathrm{~N})$ then heated again till dryness.

4) An aliquot of $15 \mathrm{ml} \mathrm{HCl}(6 \mathrm{~N})$ was added to the residue and the whole dissolved content was completed in a 250 $\mathrm{ml}$ volumetric flask.

\section{Results and Discussion}

All the obtained results concerning thorium determination using alizarin red $\mathrm{S}$ dye were discussed. Several factors were studied to optimize the formation of thorium-alizarin complex. This included the effect of different acid media, choice of the suitable buffer $\mathrm{pH}$, optimum concentration of alizarin red $\mathrm{S}$ dye, the duration time of the complex as well as the optimum concentration of thorium (calibration curve). Finally, the optimum molar ratio between metal and dye was studied.

\section{Effect of acid medium}

The effect of perchloric acid, hydrochloric acid, nitric acid and sulfuric acid with different concentrations $(\mathrm{pH})$ on complex formation were studied. To determine the optimum concentration of acidic medium, a constant volume of $1 \mathrm{ml}$ from each of the thorium stock solution $\left(10^{-3} \mathrm{M}\right)$, and alizarin red $\mathrm{S}$ dye $\left(10^{-3} \mathrm{M}\right)$ were taken, while several aliquots from different acids $(0.1 \mathrm{ml}$ to $5 \mathrm{ml})$ from $1 \mathrm{~N}, 10^{-2} \mathrm{~N}$ and $10^{-}$ ${ }^{4} \mathrm{~N}$ were added to a series of $10 \mathrm{ml}$ volumetric flasks. The absorbance of each acid concentration was measured in the range from $450-600 \mathrm{~nm}$. The obtained data illustrated in Figures $(1 \mathrm{a}, \mathrm{b}, \mathrm{c}, \mathrm{d})$ illustrated the effect of the studied acids on thorium- alizarin red $\mathrm{S}$ complex formation. The maximum absorbance value of the complex was found at withdrawing of $0.2 \mathrm{ml}$ from $10^{-2} \mathrm{~N}$ perchloric acid $\left(0.2 \times 10^{-}\right.$ $\left.{ }^{3} \mathrm{~N}, \mathrm{pH} 3.7\right)$ at $\lambda_{\max } 530 \mathrm{~nm}$. Perchloric acid was selected for optimum complex formation where it has the advantage since either nitric or hydrochloric acid can be converted easily to perchlorate medium.

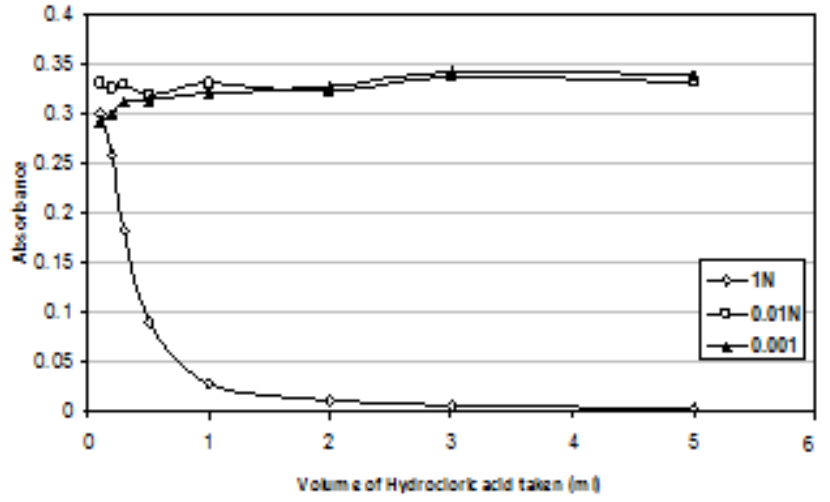

Figure (1a)

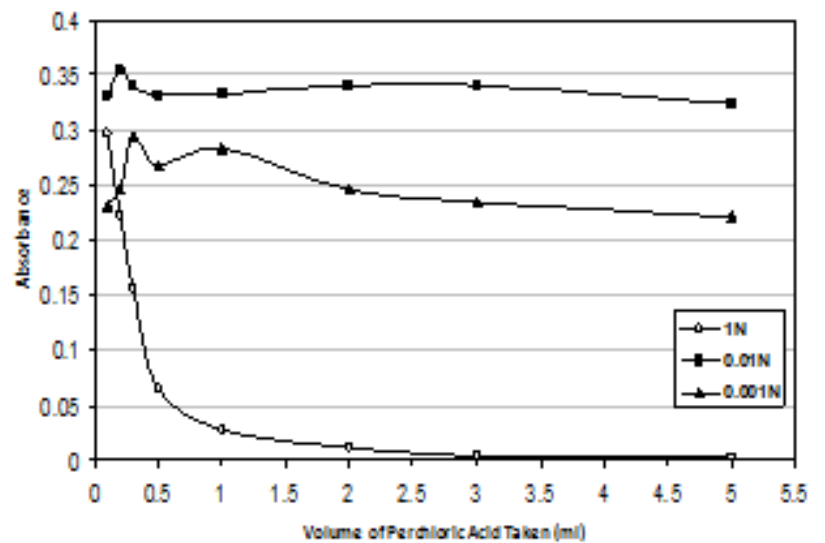

Figure (1b)

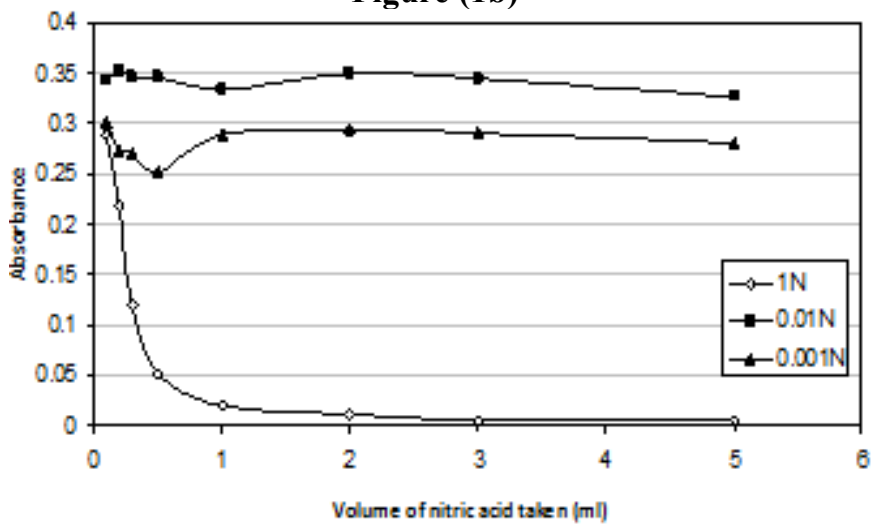

Figure (1c) 


\section{International Journal of Science and Research (IJSR)}

ISSN (Online): 2319-7064

Index Copernicus Value (2013): 6.14 | Impact Factor (2014): 5.611

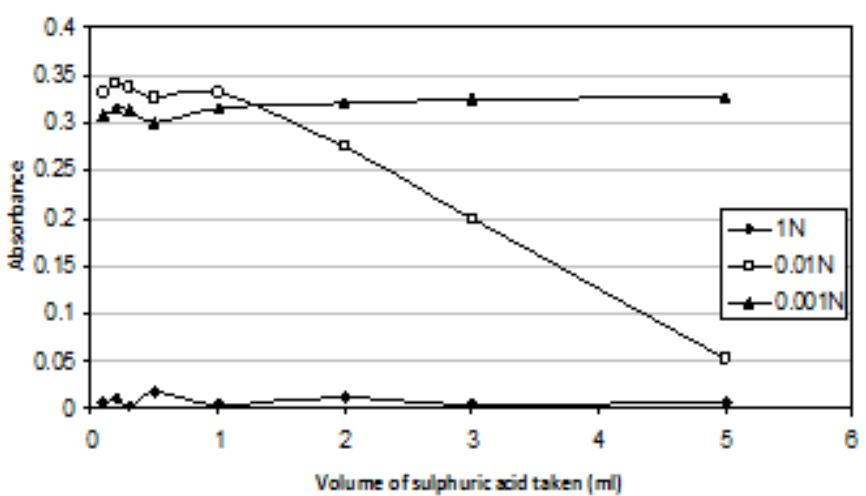

Figure (1d)

Figures (1a, 1b, 1c, 1d): Effect of different acids and their $\mathrm{pH}$ on the formation of Th-alizarin complex

\section{Choice of the suitable buffer $\mathrm{pH}$}

A buffer solution was used in this study to fix the optimum acid concentration value of complex formation. Sodium acetate $(2 \mathrm{M})$ and acetic acid $(2 \mathrm{M})$ buffer solution was prepared to give variable $\mathrm{pH}$ values $3.4,3.7$ and 4 . Each buffer solution was added to different solutions containing $1 \mathrm{ml}$ from $10^{-3} \mathrm{M}$ thorium, $0.2 \mathrm{ml}$ from $10^{-2} \mathrm{~N}$ perchloric acid and $1 \mathrm{ml}$ from $10^{-3} \mathrm{M}$ alizarin red $\mathrm{S}$ dye where the final volumes of these solutions were completed to $10 \mathrm{ml}$. The absorbance of the formed complex was measured in the wavelength range $450-600 \mathrm{~nm}$. Table (2) summarized the effect of buffer $\mathrm{pH}$ variation on the absorbance of thoriumalizarin red $\mathrm{S}$ complex. It was clearly evident that the maximum absorption of the complex at $\lambda_{\max } 530 \mathrm{~nm}$ was by addition of $0.5 \mathrm{ml}$ from buffer $\mathrm{pH} 3.4$.

Table 2: Effect of buffer $\mathrm{pH}$ on the absorbance of thoriumalizarin red $\mathrm{S}$ complex

\begin{tabular}{|c|c|c|c|}
\hline $\begin{array}{c}\text { Volume of buffer } \\
\text { ml }\end{array}$ & $\mathrm{pH} \mathrm{3.4}$ & $\mathrm{pH} 3.7$ & $\mathrm{pH} 4$ \\
\cline { 2 - 4 } $\boldsymbol{\lambda} \mathbf{n m} \mid$ Abs. & $\boldsymbol{\lambda} \mathbf{\text { nm}} \mid$ Abs. & $\boldsymbol{\lambda} \mathbf{~ n m} \mid$ Abs. \\
\hline 0.1 & $530 \mid 0.351$ & $530 \mid 0.351$ & $530 \mid 0.353$ \\
\hline 0.2 & $530 \mid 0.355$ & $530 \mid 0.342$ & $530 \mid 0.345$ \\
\hline 0.3 & $530 \mid 0.350$ & $530 \mid 0.340$ & $528 \mid 0.343$ \\
\hline 0.5 & $530 \mid 0.359$ & $530 \mid 0.340$ & $528 \mid 0.338$ \\
\hline 1 & $522 \mid 0.346$ & $528 \mid 0.337$ & $522 \mid 0.331$ \\
\hline 1.5 & $524 \mid 0.331$ & $528 \mid 0.335$ & $522 \mid 0.326$ \\
\hline 2 & $522 \mid 0.331$ & $528 \mid 0.327$ & $520 \mid 0.324$ \\
\hline 2.5 & $520 \mid 0.328$ & $522 \mid 0.325$ & $520 \mid 0.320$ \\
\hline 3 & $518 \mid 0.324$ & $522 \mid 0.320$ & $520 \mid 0.318$ \\
\hline
\end{tabular}

Effect of alizarin red $S$ dye concentration on the absorbance of thorium complex by molar ratio method It was evidently known that the dye concentration should be optimized since any variation in its concentration may cause deviation from Beer's law. In this experiment different volumes from $10^{-3} \mathrm{M}$ alizarin red $\mathrm{S}$ dye solution were added in a series of $10 \mathrm{ml}$ volumetric flasks with fixed concentration of thorium $\left(1 \mathrm{ml}\right.$ from $\left.10^{-3} \mathrm{M}\right), 0.2 \mathrm{ml}$ from $10^{-2}$ $\mathrm{N}$ perchloric acid and $0.5 \mathrm{ml}$ from acetate buffer $\mathrm{pH}$ 3.4. The final volume was completed to $10 \mathrm{ml}$ with double distilled water. The absorbance of each solution was measured at $\lambda_{\max }$ $530 \mathrm{~nm}$. The molar ratio method showed that the concentration of the dye required to form stable thoriumalizarin red S complex with high absorbance at $\lambda_{\max } 530 \mathrm{~nm}$ was at $4 \times 10^{-4} \mathrm{M}$ of the dye $\left(4 \mathrm{ml}\right.$ from $\left.10^{-3} \mathrm{M}\right)$ and the ratio between thorium [M] and alizarin red $\mathrm{S}$ dye [L] at high absorbance was $[\mathrm{L}]:[\mathrm{M}]=4: 1$ as shown in Figure (2).

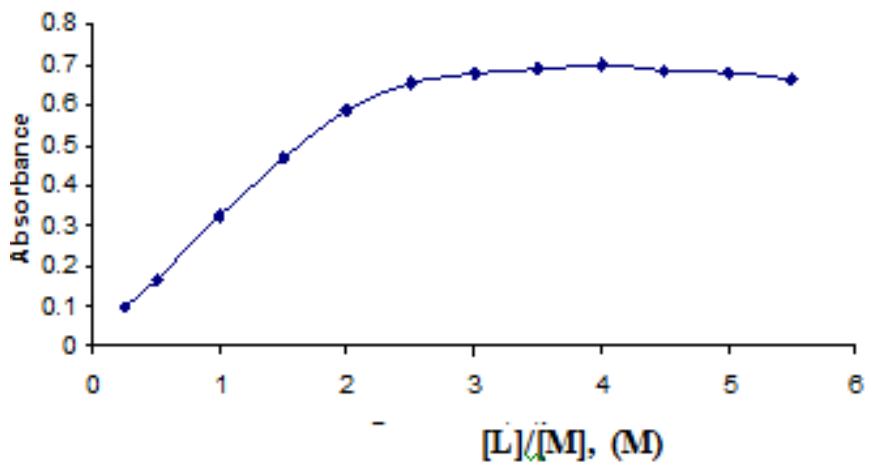

Figure 2: Effect of alizarin red $\mathrm{S}$ dye concentration on the absorbance of thorium complex

\section{Effect of duration time on the stability of thorium} complex

The stability of thorium - alizarin red S complex was tested over a period of time, where the absorbance was measured periodically every 5 minutes. It was found that the complex was stable for 25 minutes after which it began to dissociate slowly as shown in Table (3).

Table 3: Effect of duration time on the stability of thorium alizarin red S complex

\begin{tabular}{|c|c|}
\hline Time (minutes) & Abs. at $\lambda_{\max } 530 \mathrm{~nm}$ \\
\hline Zero & 0.775 \\
\hline 5 & 0.778 \\
\hline 10 & 0.779 \\
\hline 15 & 0.779 \\
\hline 20 & 0.779 \\
\hline 25 & 0.775 \\
\hline 30 & 0.768 \\
\hline 35 & 0.767 \\
\hline 40 & 0.766 \\
\hline 45 & 0.760 \\
\hline 50 & 0.754 \\
\hline 55 & 0.748 \\
\hline 60 & 0.543 \\
\hline
\end{tabular}

\section{Construction of calibration curve}

According to Beer's law it was necessary to determine the maximum and minimum thorium detectable concentrations, for this purpose a series of thorium concentrations were prepared while fixing the concentration of perchloric acid $0.2 \mathrm{ml}$ from $10^{-2} \mathrm{~N}, 0.5 \mathrm{ml}$ from buffer $\mathrm{pH} 3.4$ and $4 \mathrm{ml}$ from $10^{-3} \mathrm{M}$ alizarin red $\mathrm{S}$ dye. The absorbance of each complex was measured at the recommended $\lambda_{\max } 530 \mathrm{~nm}$ against a proper blank solution. Beer's law was obeyed from a minimum detectable thorium concentration of $1 \mathrm{ppm}$ till a maximum concentration of $80 \mathrm{ppm}$ after which a plateau was formed. Figure (3) indicated the working calibration curve for thorium determination. 


\section{International Journal of Science and Research (IJSR) ISSN (Online): 2319-7064}

Index Copernicus Value (2013): 6.14 | Impact Factor (2014): 5.611

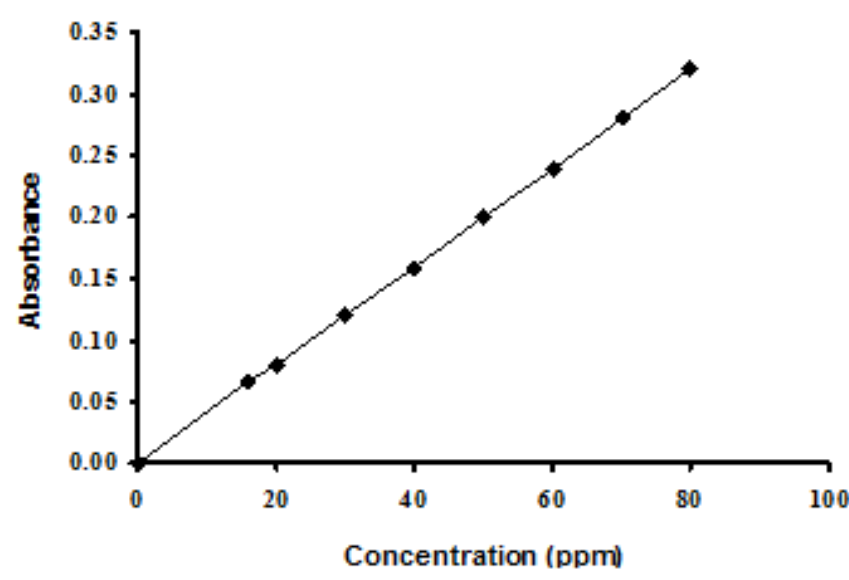

Figure 3: Calibration curve of thorium using alizarin red $\mathrm{S}$ dye

The interference effect on spectrophotometric determination of thorium using alizarin red $S$

It was necessary to study the interference effect of some associated elements with thorium in different rock types which may react similarly under the same conditions. The effect of different concentrations of anions and cations on thorium $\left(2.5 \mathrm{\mu gml}^{-1}\right)$ determination using alizarin red $\mathrm{S}$ were studied using the previously optimized additions $(0.2 \mathrm{ml}$ from $10^{-2} \mathrm{~N}$ perchloric acid, $0.5 \mathrm{ml}$ of acetate buffer solution $\mathrm{pH} 3.4$ and $4 \mathrm{ml}$ from $10^{-3} \mathrm{~N}$ alizarin red $\mathrm{S}$ dye). Table (4) summarized the tolerance limits of interfering ions on thorium determination by alizarin red $\mathrm{S}$ dye.

Table 4: Influence of interfering ions on the determination of thorium

\begin{tabular}{|c|c|}
\hline Interfering ion & $\begin{array}{c}\text { Tolerance limit }(\mu \mathrm{g} \mathrm{ml} \\
\left.{ }^{1}\right)\end{array}$ \\
\hline $\mathrm{PO}_{4}{ }^{3-}$ & 1000 \\
\hline $\begin{array}{c}\mathrm{Al}^{3+}, \mathrm{Co}^{3+}, \mathrm{Cu}^{2+}, \mathrm{Ca}^{2+}, \\
\mathrm{Mg}^{2+}, \mathrm{Ni}^{2+}, \mathrm{Mn}^{2+}, \mathrm{Ba}^{2+}, \mathrm{Zn}^{2+}\end{array}$ & 1000 \\
\hline $\mathrm{Cd}^{2+}$ & 500 \\
\hline $\mathrm{Fe}^{3+}, \mathrm{VO}^{2+}$ & 100 \\
\hline $\mathrm{UO}_{2}{ }^{2+}$ & 18 \\
\hline
\end{tabular}

\section{Application of the studied method on different rock types} bearing thorium

After optimization of the developed spectrophotometric method for thorium determination using alizarin red $\mathrm{S}$ dye, several rock types bearing thorium were selected with different matrices namely; thorite, trachyte, ring complex, basmatic gneiss together with standard phosphate (2) [19] for thorium determination using the present studied alizarin red $\mathrm{S}$ dye. Thorite, a thorium uranium silicate from igneous pegmatite and volcanic rocks, hydrothermal veins and contact metamorphic rocks, it is also known to occur as small grains in detrital sands. Trachyte, from East Basin Kom Ombo - Aswan, is an igneous volcanic rock equivalent to syenite. The mineral assemblage consists of essential alkali feldspar; relatively minor plagioclase and quartz. Ring complex from North El Atshan, Eastern Desert, Egypt is a circular $2 \mathrm{~km}$ in diameter igneous ring complex that intrudes upper Palaeozoic volcanics and granites, its outer ring consists of feldspathoidal igneous rocks. These rocks consist of orthoclase, albite, aegirine-augite, sodic amphibole, biotite, zeolites, pyrochlore and apatite. Basmetic gneiss from Abo Rusheid, Eastern Desert was formed by the metamorphism of arenaceous sediments.

The major oxides in the selected rock samples bearing thorium were analyzed [20] and thorium was analyzed using a well known analytical method for determination [21], Table (5).

Table 5: Complete analysis of selected applied samples for thorium determination

\begin{tabular}{|c|c|c|c|c|c|}
\hline Sample ID & Trachyte & $\begin{array}{c}\text { Ring } \\
\text { complex }\end{array}$ & $\begin{array}{c}\text { Basmatic } \\
\text { gneiss }\end{array}$ & Thorite & $\begin{array}{c}\text { Standard } \\
\text { phosphate } \\
2\end{array}$ \\
\hline $\mathrm{SiO}_{2}$ & 63.4 & 54.94 & 71.98 & 83.3 & 8.74 \\
\hline $\mathrm{Al}_{2} \mathrm{O}_{3}$ & 15.49 & 13.69 & 13.18 & 6.66 & 1.62 \\
\hline $\mathrm{Fe}_{2} \mathrm{O}_{3}$ (total) & 4.75 & 9.75 & 1.49 & 0.22 & 1.34 \\
\hline $\mathrm{MgO}$ & 1.86 & 8.5 & 2.93 & 0.06 & 4.98 \\
\hline $\mathrm{CaO}$ & 2.6 & 8.41 & 3.69 & 0.62 & 37.99 \\
\hline $\mathrm{Na}_{2} \mathrm{O}$ & 6.39 & 2.43 & 3.76 & 0.34 & 0.78 \\
\hline $\mathrm{K}_{2} \mathrm{O}$ & 4.08 & 0.93 & 2.97 & 0.17 & 0.18 \\
\hline $\mathrm{TiO}_{2}$ & 0.069 & 0.049 & 0.035 & 0.43 & 0.07 \\
\hline $\mathrm{P}_{2} \mathrm{O}_{5}$ & 0.08 & 0.07 & 0.05 & 1.2 & 20.6 \\
\hline $\mathrm{Th}_{2}(\mathrm{ppm})$ & 21.50 & 20.50 & 19.00 & 1330 & 21.40 \\
\hline $\mathrm{U}(\mathrm{ppm})$ & 1400 & 1298 & 837 & 320 & 2.09 \\
\hline
\end{tabular}

From Table (5) it was clearly evident that there were several points to be mentioned; first, the severe interference effect due to the high concentration values of the interfering accompanying major oxides (as studied in Table 4) which are present in percentage in all samples with respect to thorium concentration found in $\mu \mathrm{g} / \mathrm{ml}$. Second, the interference due to presence of high uranium concentration in some samples, as Trachyte, Ring complex and Basmatic gneiss, which interfered due to its concentration ratio to thorium was more than six $(\mathrm{U}: \mathrm{Th}>6: 1)$ [21].

The high major oxides concentration was overcome by proposing a developed decomposition method [18] for all samples which minimized their concentration values as shown in Table (6). The high uranium concentration in some samples was treated by using trioctylamine as a selective solvent for uranium [21]. After separation of uranium, thorium was analyzed in the aqueous solution using the developed alizarin dye with good accuracy, Table (7). After those treatments the thorium concentration analyzed by the present developed alizarin red S dye was very close to the true values which referred that it has overcome successfully the interference effect during thorium determination. 


\section{International Journal of Science and Research (IJSR) \\ ISSN (Online): 2319-7064 \\ Index Copernicus Value (2013): 6.14 | Impact Factor (2014): 5.611}

Table 6: Comparative study between the complete and developed decomposition for Th determination in different rocks

\begin{tabular}{|c|c|c|c|c|c|c|c|c|c|c|}
\hline \multirow{2}{*}{\begin{tabular}{|l} 
Sample \\
Oxide (\%) \\
\end{tabular}} & \multicolumn{2}{|c|}{ Thorite } & \multicolumn{2}{|c|}{ Trachyte } & \multicolumn{2}{|c|}{ Ring complex } & \multicolumn{2}{|c|}{ Basmatic gneiss } & \multicolumn{2}{|c|}{ Standard phosphate (2) } \\
\hline & C.D & Developed & C.D & Developed & C.D & Developed & C.D & Developed & C.D & Developed \\
\hline $\mathrm{SiO}_{2}$ & 83.3 & 1.65 & 63.4 & 1.31 & 54.94 & 1.07 & 71.98 & 1.97 & 8.74 & 0.37 \\
\hline $\mathrm{Al}_{2} \mathrm{O}_{3}$ & 6.66 & 0.64 & 15.49 & 1.82 & 13.69 & 1.61 & 13.18 & 1.43 & 1.62 & 0.08 \\
\hline $\mathrm{Fe}_{2} \mathrm{O}_{3}$ (total) & 0.22 & 0.04 & 4.75 & 0.74 & 9.75 & 0.98 & 1.49 & 0.081 & 1.34 & 0.07 \\
\hline $\mathrm{MgO}$ & 0.06 & 0.02 & 1.86 & 0.05 & 8.5 & 1.65 & 2.93 & 0.075 & 4.98 & 0.27 \\
\hline $\mathrm{CaO}$ & 0.62 & 0.07 & 2.6 & 0.09 & 8.41 & 1.31 & 3.69 & 0.067 & 37.99 & 0.86 \\
\hline $\mathrm{Na}_{2} \mathrm{O}$ & 0.34 & 0.04 & 6.39 & 0.7 & 2.43 & 0.053 & 3.76 & 0.074 & 0.78 & 0.08 \\
\hline $\mathrm{K}_{2} \mathrm{O}$ & 0.17 & 0.02 & 4.08 & 0.82 & 0.93 & 0.04 & 2.97 & 0.039 & 0.18 & 0.02 \\
\hline $\mathrm{TiO}_{2}$ & 0.43 & 0.06 & 0.069 & 0.02 & 0.049 & 0.01 & 0.035 & 0.013 & 0.07 & 0.03 \\
\hline $\mathrm{P}_{2} \mathrm{O}_{5}$ & 1.2 & 0.06 & 0.08 & 0.04 & 0.07 & 0.03 & 0.05 & 0.021 & 20.6 & 0.53 \\
\hline Th ppm & 40000 & 1325 & 647 & 20.63 & 957 & 19.20 & 1143 & 17.47 & 591 & 18.5 \\
\hline U ppm & \multicolumn{2}{|l|}{320} & \multicolumn{2}{|l|}{1400} & \multicolumn{2}{|l|}{1298} & \multicolumn{2}{|l|}{837} & \multicolumn{2}{|c|}{2.09} \\
\hline
\end{tabular}

\section{C.D means complete decomposition}

From results gathered in Table (6), it was clear that only partial decomposition of accompanying major oxides together with nearly total leaching percentage of thorium were reached which facilitated for an accurate determination of thorium in different rock types.

Table 7: Determination of thorium in different rock samples using alizarin red S dye method after uranium separation

\begin{tabular}{|c|c|c|}
\hline Sample & $\begin{array}{c}\text { Concentration of } \\
\text { thorium using Alizarin } \\
\text { red S dye method }(\mu \mathrm{g} \\
\left.\mathrm{ml}^{-1}\right)\end{array}$ & $\begin{array}{c}\text { Thorium } \\
\text { concentration using } \\
\text { TOPO method }(\mu \mathrm{g} \\
\left.\mathrm{ml}^{-1}\right)\end{array}$ \\
\hline Thorite & 1325 & 1330 \\
\hline Trachyte & 20.63 & 21.5 \\
\hline Ring Complex & 19.2 & 20.5 \\
\hline Basmatic Gneiss & 17.47 & 19.0 \\
\hline Standard phosphate 2 & 18.5 & 21.4 \\
\hline
\end{tabular}

\section{Conclusion}

A developed spectrophotometric analysis for thorium using a well known chromogenic dye, alizarin red S, was used. Several parameters were studied for the optimization of the formed thorium-alizarin red $\mathrm{S}$ complex namely; effect of different acid media $(\mathrm{pH})$, optimum buffer $\mathrm{pH}$, dye concentration, duration of the stability of the complex and thorium concentration (calibration curve). The optimized method was applied to different rock types bearing thorium with different thorium concentrations and matrices. Interference due to high uranium concentration in some samples such as Trachyte, ring complex and basmatic gneiss was overcome by the selective extraction of uranium, whereas the interference due to some major oxides was treated using a developed method for decomposition which minimized greatly their concentrations and treated the drastic effect of the accompanying interfering major oxides without further separation methods. The method was proved to be accurate with a percentage relative standard deviation value of $2.32 \%$.

\section{Acknowledgement}

The authors wishes to thank Professor Doctor Mohamed Ahmed, Nuclear Materials Authority, for his kind help in supplying different rock samples used in the application part in this article.

\section{References}

[1] Jessica Cerezo, "Automated flow systems for total and isotopic analysis of thorium and uranium in samples of environmental interest", Ph.D Thesis, Palma de Mallorca, February 2012

[2] S.B. Savvin; Talanta; 8, 673 (1961)

[3] G. Banerjee; J. Anal. Chem; 16, 56 (1957).

[4] R.S. Boitei and P.L. Gerace; J. lnorg. Nucl. Chem; 21, 265 (1961).

[5] O. Menis, D.L. Manning and G. Goldstin; J. Anal. Chem; 29, 1426 (1957).

[6] M.H. Fletcher and R.G. Milkey; J. Anal. Chem; 28, 1402 (1956).

[7] J.B. Ghasemi and E. Zolfonoun; Talanta; 80, 1191 (2010).

[8] A.R. Plamer; J. Anal. Chim. Acta; 19, 458 (1958).

[9] Tetsuya Kiriyama, Rokuro Kuroda, Microchimica Acta, 1985, v. 87(5) p. 369-375

[10] S.P. Sangal, Microchemical J. 12, 326, (1967)

[11]A.K. Dey, Mikrochim. Acta, 2-4, 414, (1964)

[12] G. Jo, M. Won, Y. Shim, Electroanalysis II, 885 (1999)

[13] J. Zhang, J. Li, P. Deng, Talanta, 54, 561 (2001).

[14]D. Junwei, B. Shuping, Y. Tianyu, M. Zhang, Sensors and Actuators B, 99, 468 (2004).

[15] S. Hajizadeh, A.E. Ivanov, M. Jahanshahi, M.H. Sanati, N.V. Zhuravleva, L.I. Mikhalovaska, I.V. Galaev, Reactive and Functional Polymer, 68, 1625 (2008)

[16]A. Abbaspour, L. Baramakeh, Anal. Sci., 18, 1127 (2002)

[17] M. Nejati- Yazdinejad, Anal. Sci., 22, 617 (2006).

[18] S.Y. Afifi M.M. Mustafa, E.M. El Sheikh, M.A. Gado, Arab Sci. Nucl. Sci. Appl., 45(3), (2012).

[19] M.M. Aly, "Analysis of the second phosphate standard of the Egyptian nuclear materials corporation", Proceedings of the Second Conference on Optical Spectroscopy, LASER, and their applications, p. 376 (1985).

[20] L. Shappiro and W.W. Brannock, "Rapid Analysis of Silicates, Carbonates and Phosphate Rocks", US Geol. Survey Bulletin 1144A (1962).

[21]Fukuma, H.T., Fernandes, E.A.N., Nascimento, M.R.L.,Quinelato, 1A.L. "Separation and spectrophotometric determination of thorium contained in uranium concentrate", Journal of Radioanalytical and Nuclear Chemistry. 248(3), p. 549 (2001). 